\title{
Stories Notebook about the Fundamental Concepts in Family Medicine: An Introduction
}

\section{Jose Luis Turabian}

Health Center Santa Maria de Benquerencia Toledo, Spain

"Corresponding author: Jose Luis Turabian, Health Center Santa Maria de Benquerencia Toledo, Spain, Tel: 34925154508; E-mail: jturabianf@hotmail.com

Received date: January 09, 2017; Accepted date: January 25, 2017; Published date: February 01, 2017

Copyright: (c) 2017 Turabian JL. This is an open-access article distributed under the terms of the Creative Commons Attribution License, which permits unrestricted use, distribution, and reproduction in any medium, provided the original author and source are credited

\section{Introduction}

These stories of the "notebook about the fundamental concepts in family medicine" are fables that illustrate important medical concepts.

Evidence-Based Medicine, clinical trials and quantitative studies are necessary, indispensable for medical science, yes, but why not the stories, the tales and the cases? Medical science suffers from a kind of agnosia which avoids matters related to contextual judgment, the particular, the personal, and is made exclusively abstract and statistical. But the quantitative and the Evidence-Based Medicine cannot give us integral responses. So, as Oliver Sacks says, in this series of articles, we have been forced to speak of fables.

With this introduction, the Journal of General Practice begins a new section. It will be a space where the fundamental concepts of Family Medicine/General Medicine will be presented. A short text on a concept will appear in each issue of the Journal of General Practice. These will be fables.

Conceptual systematization in the specialty of Family Medicine/ General Medicine has not matched with practice. However, it is not until that the conceptual heritage of Family Medicine, is ordered, systematized and fully clarified when it can begin the real practical work. Therefore, it is necessary to achieve more meaningful representations of the fundamental concepts of Family Medicine, and facilitate the transfer of these to clinical practice. But, these concepts can be difficult to understand and explain, even for experienced physicians in the specialty.

As Stendhal says about Rome, "You can propose to see everything in Rome, but the visitor will get an excruciating headache and then satiety and pain incapacitate him for all pleasure. It is about seeing only that which interests us, rejecting the "method of museum", avoiding the systematic or habitual path, regulated or precise, avoiding the indigestion of subjects" [1].

Thus, we propose the following concepts of Family Medicine/ General Medicine, which we think are the main (and, of course, many others of importance are left out of this list) [2]:
1. Comprehensiveness and integrality
2. Continuity
3. Context and contextualization
4. Uncertainty
5. Complexity
6. Community
7. Patient-centered Interview
8. Biopsicosocial Model

9. Actors and resources/strengths of the patients

10. Medicalización and technology

11. Family

12. Symptoms

13. Diagnosis and treatment

14. Concept of health and disease

15. Variability

And, they will be presented by fables.

The fable is an adult education method that can serve to intuitively understand abstract concepts by linking them to specific situations, for facilitating their assimilation [3-7]. So, animals, plants, minerals and other things will be "patients" in consultation with the family doctor. They will be fictional stories presented as real. They will be beings or objects that are given the opportunity to think, feel and speak. In the fable it can be distinguished two parts: one is the story itself; and the other the moral. Each story seeks to make emerge, of clear form, the moral at the end of the fable, as sobering consequence of what happened in the episode. The moral is concise and brief, so that it can be easily etched in the minds of readers. It will be 15 fables which illustrating these 15 fundamental concepts of Family Medicine/General Medicine.

The titles of these 15 fables will be:

1. Comprehensiveness and integrality

THE TREE AND THE GRASS

2. Continuity

THE RIVER WITH MEANDERS

3. Context and contextualization

THE SEAGUlL, THE DOVE, THE CROW AND THE ALBATROSS

4. Uncertainty

THE ZEBRA AND THE HORSE

5. Complexity

THE BUFFALO AND THE BISON

6. Community

THE COIN WITH TWO SIDES

7. Patient-centered Interview

THE FRIED EGG AND THE YOLK-CENTERED INTERVIEW 


\author{
8. Biopsicosocial Model \\ THE SPONGE CAKE, THE CREAMY CAKE, AND THE \\ CRUNCHY CAKE
}

9. Actors and resources/strengths of the patients

THE SANDWICH AND THE CHEESEBURGER

10. Medicalization and technology

THE BIRD AND THE TREE BRANCHES

11. Family

THE AMERICAN BILLIARD BALL

12. Symptoms

\section{THE BEAR IN ZOO CAGE AND THE BEAR IN FREEDOM}

13. Diagnosis and treatment

\section{THE CROCODILE TEARS}

14. Concept of health and disease

\section{THE TUNNEL AND THE BRIDGE}

15. Variability

THE WHALE AND THE MICROBE, THE GIRAFFE AND THE FLEA

The family doctor is a general practitioner (GP) who takes professional responsibility for the comprehensive care of unselected patients with undifferentiated problems and is committed to the person regardless of age, sex, disease, or organs or body systems. Family doctors/GPs have shown that the theoretical framework within which they operate is different, complementary, and not less demanding than other medical specialists.

Family doctors/GPs must achieve a diagnostic and therapeutic knowledge of biomedical science but they should apply this knowledge throughout ongoing relationships with a variety of individual patients. So, they need to understand that the disease process is socially constructed within the patient's life, and they have to mediate between the subjective experience of illness of the patient and scientific explanation. Family Medicine/General Medicine is special, not so much because of the depth of their expertise about the complexity of a specific biomedical area, but about the complexity of contextualization of medical care in the patient.

The characteristic of Family Medicine is the understanding of the patient and their disease based not only on symptoms and signs but in the psychological and social factors relating to patient context. Family Medicine is a specialty with horizontal amplitude of clinical predominance, which shares the knowledge and skills of other specialties and integrates the biomedical, behavioral and social sciences [8-12]. The characteristic of Family Medicine is the understanding of the patient and their disease based not only on symptoms and signs but in the psychological and social factors relating to patient context. Family Medicine is a specialty with horizontal amplitude of clinical predominance, which shares the knowledge and skills of other specialties and integrates the biomedical, behavioral and social sciences [3-7].

Family physicians/GPs do not treat diseases but take care of people. And so, a major feature of General Medicine is that you cannot separate the physical from the psychic. It is the only medical specialty where this inevitable gap does not occur. The stories, tales and fables, belong inseparably to both sides, and they serve precisely to save that abyss [1], to take us to the intersection of the objective and the subjective, the quantitative and the qualitative, the physical and the psychic, the pathology and the experience of the disease.

\section{References}

1. Stendhal (2007) Paseos por Roma. Madrid: Alianza Editorial.

2. Turabian JL (1995) Cuadernos de Medicina de Familia y Comunitaria. Una introducción a los principios de Medicina de Familia. Family and Community Medicine notebooks. An Introduction to the Principles of Family Medicine. Madrid: Díaz de Santos.

3. Hesse M (1966) Models and analogies in science. (1st edtn). University of Notre Dame Press, Notre Dame, USA.

4. Gross A (1990) The rhetoric of science. Harvard University Press, Cambridge, USA.

5. Thomas P (2006) General medical practitioners need to be aware of the theories on which our work depends. Ann Fam Med 4: 450-454.

6. Olesen F (2003) A framework for clinical general practice and for research and teaching in the discipline. Fam Pract 20: 318-323. http:// fampra.oxfordjournals.org/content/20/3/318.full

7. Turabian JL, Perez-Franco B (2016) The Family Doctors: Images and Metaphors of the Family Doctor to Learn Family Medicine. J Gen Pract 4: 273.

8. Davies P (2000) Is it time for a new definition of general practice? General practitioners' main interest is people. BMJ 321: 173.

9. Turabian JL (1995) Cuadernos de Medicina de Familia y Comunitaria. Una introducción a los principios de Medicina de Familia. [Family and Community Medicine notebooks. An Introduction to the Principles of Family Medicine]. Madrid: Díaz de Santos.

10. Epstein RM, Hundert EM (2002) Defining and Assessing Professional Competence. JAMA 287: 226-235.

11. Engel CL (1980) The clinical application of the biopsychosocial model. Am J Psychiatry 137: 535.

12. McWhinney IR (1989) A textbook of Family Medicine. Oxford University Press, New York, USA.

13. Sacks O (1998) The man who mistook his wife for a hat. New York: Touchstone, New York, USA. 